\title{
A INTEGRALIDADE DO DIREITO À SAÚDE NA VISÃO DO SUPREMO TRIBUNAL FEDERAL
}

The integrality of the right to health in the view of the Brazilian Federal Supreme Court

${ }^{1}$ Universidade São Judas Tadeu. São Paulo/SP, Brasil.

Correspondência: lunadacunha@yahoo.com.br

Recebido: 13/01/2018. Revisão: 22/11/2018. Nova revisão: 27/11/2018. Aprovado: $27 / 11 / 2018$. 


\section{RESUMO}

A Constituição de 1988 inovou o ordenamento jurídico brasileiro ao estabelecer o direito à saúde como direito de todos e dever do Estado, dotado de uma universalidade tanto objetiva quanto subjetiva. Mas será que é possível a realização imediata dessa universalidade? Ao mesmo tempo em que a Constituição prevê a dupla vertente da universalidade, ela a restringe, por meio de outros dois objetivos da seguridade social: seletividade e distributividade. Além disso, o próprio regime jurídico dos direitos sociais estabelece que sua concretização deverá ser efetuada de forma progressiva e com a aplicação do máximo de recursos disponíveis. Dessa forma, fundamental é a análise da jurisprudência do Supremo Tribunal Federal para uma interpretação que permita compreender o conceito de integralidade do direito à saúde.

\section{Palavras-Chave}

Direito à Saúde; Integralidade; Supremo Tribunal Federal; Universalidade.

\section{ABSTRACT}

The 1988 Constitution innovated the Brazilian legal framework establishing the right to health as a right of all the people and a duty of the State, providing of an objective and subjective universality. But is it possible the immediate realization of this universality? While the Constitution provides the double strand of universality, it restricts this universality through two other objectives of social security, selectivity and distributivity. Moreover, the very juridical regime of social rights establishes that its implementation should be done gradually and with the application of the maximum available resources. Therefore, the analysis of the Brazilian Federal Supreme Court jurisprudence is fundamental for an interpretation that allows understanding the concept of integrality of the right to health.

\section{Keywords}

Right to Health; Integrality; Brazilian Federal Supreme Court; Universality. 


\section{Introdução}

Victor Fuchs ${ }^{1}$, professor da Universidade de Stanford, afirma que, nos Estados Unidos, a crise na garantia da saúde da população pode ser atribuída a dois componentes: o restrito acesso às ações e aos serviços de saúde e o custo da concretização do referido direito.

Não é complicado compreender a problemática do acesso e do custo do direito à saúde nos Estados Unidos. Com a existência de apenas dois planos públicos de saúde, o Medicare e o Medicaid, grande parte da população norte-americana resta completamente descoberta em eventuais contingências sanitárias.

Ao mesmo tempo em que há uma imensa restrição quanto à universalidade subjetiva nos Estados Unidos, o custo para a manutenção desse sistema desigual de saúde é assustador. Segundo dados da Organização para a Cooperação e Desenvolvimento Econômico² (OECD), os Estados Unidos gastaram, em 2017, US\$10.209,00 em saúde por habitante, valor muito maior do que a média dos países-membros da OECD, que investem aproximadamente US\$ 4.069,00.

Pois bem, no Brasil, teoricamente, não teríamos esse problema. A Constituição de $1988^{3}$ (CF/88), ao contrário das constituições brasileiras anteriores, garantiu, pela primeira vez, o direito à saúde como um direito social, sendo as ações e os serviços universais e igualitários de saúde um direito de todos e dever do Estado.

Essa integralidade do direito à saúde atingiu patamares antes não vistos no Direito brasileiro, já que a CF/88 ampliou o acesso à cobertura das ações e dos serviços de saúde para toda a população - em detrimento da estrutura anterior, que abrangia, dentro da proteção ao direito à saúde, apenas os segurados e dependentes do sistema de previdência social.

Ao mesmo tempo, o artigo 195 da CF/88 estabeleceu uma ampla fonte de financiamento da seguridade social, que inclui o direito à saúde, competindo a toda a sociedade seu financiamento, seja de forma direta, seja de forma indireta, e abarcando tanto recursos do orçamento fiscal quanto recursos do orçamento da seguridade social.

Então, ao menos em tese, não teríamos um problema quanto ao acesso e ao financiamento do direito à saúde. Ou teríamos? Essa análise será baseada na metodologia da pesquisa teórica e jurisprudencial. A pesquisa jurisprudencial permitirá indicar o atual entendimento do Superior Tribunal Federal (STF), expressando sua visão acerca da extensão da integralidade do direito à saúde. Esse entendimento

${ }^{1}$ FUCHS, Victor R. The future of health policy. 3. reprint. Harvard: Harvard University Press, 1997. p. 11. ${ }^{2}$ ORGANIZATION FOR ECONOMIC COOPERATION AND DEVELOPMENT - OECD. Spending on health: latest trends. Disponivel em: http://www.oecd.org/els/health-systems/health-data.htm. Acesso em: Nov. 20, 2018.

${ }^{3}$ BRASIL. Constituição da República Federativa do Brasil de 1988. Disponível em: http://www.planalto.gov. br/ccivil_03/constituicao/constituicaocompilado.htm. Acesso em: 25 set. 2019. 
será demonstrado pela análise das decisões que o próprio STF vem reiterando como paradigmáticas e que são citadas à exaustão nos julgamentos que as seguiram.

\section{Direito à saúde}

A problemática da integralidade do direito à saúde torna imperiosa a reflexão acerca dos conceitos jurídicos de direitos fundamentais e direitos sociais para que se possa localizar o correto enquadramento dessa integralidade.

Após a promulgação da CF/88, a doutrina pátria debruçou-se com intensidade sobre a reflexão da temática dos direitos fundamentais. José Afonso da Silva ${ }^{4}$ construiu o seguinte conceito de direitos fundamentais: "prerrogativas e instituições que o direito positivo concretiza em garantia de uma convivência digna, livre e igual de todas as pessoas."

Na manifestação de Paulo Bonavides, a conceituação de direitos fundamentais está relacionada à própria razão de ser do Estado Social e Democrático de Direito, afirmando:

[...] os direitos fundamentais em harmonia com os postulados do Estado Social e democrático de Direito pode iluminar e guiar a reflexão do jurista [...] que tem por si a base de legitimidade haurida na tábua dos princípios gravados na própria constituição (arts. $1^{\circ}$., $3^{\circ}$. e 170) que fazem irrecusavelmente inconstitucional toda inteligência restritiva da locução jurídica "direitos e garantias individuais” (art. $60, \S 4^{\circ}$., IV), a qual não pode, assim, servir de argumento nem de esteio à exclusão dos direitos sociais ${ }^{5}$.

José Afonso da Silva estabelece o seguinte conceito de direitos sociais:

Dimensão dos direitos fundamentais representada por prestações positivas proporcionadas pelo Estado direta ou indiretamente, enunciadas em normas constitucionais, que possibilitam melhores condições de vida aos mais fracos, direitos que tendem a realizar a igualização de situações sociais desiguais ${ }^{6}$.

O autor conclui afirmando que os direitos sociais são direitos fundamentais e, por isso, gozam das mesmas prerrogativas e proteções dos direitos fundamentais previstos de forma expressa na $\mathrm{CF} / 88$, e o faz da seguinte forma: “[...] direitos fundamentais do homem-social, que constituem os direitos assegurados ao homem em suas relações sociais e culturais (art. $6^{\circ} .:$ saúde) ${ }^{7 ”}$ (destaque do autor). Expressa seu entendimento afirmando de forma categórica:

\footnotetext{
${ }^{4}$ SILVA, José Afonso da. Curso de direito constitucional positivo. 32. ed. São Paulo: Malheiros, 2008. p. 178. ${ }^{5}$ BONAVIDES, Paulo. Curso de direito constitucional. 24. ed. São Paulo: Malheiros, 2009. p. 659-660. ${ }^{6}$ SILVA, José Afonso da. op. cit., p. 286-287.

${ }^{7}$ Id. Ibid., p. 184.
} 
A Constituição, agora, fundamenta o entendimento de que as categorias de direitos humanos fundamentais, nela previstos, integram-se num todo harmônico, mediante influências recíprocas, até porque os direitos individuais, consubstanciados no seu art. $5^{\circ}$., estão contaminados de dimensão social ${ }^{8}$.

Para, finalmente, afirmar a impossibilidade de separação entre direitos fundamentais e sociais:

É espantoso como um bem extraordinariamente relevante à vida humana só agora é elevado à condição de direito fundamental do homem.

[...] nos casos de doença, cada um tem o direito a um tratamento condigno de acordo com o estado atual da ciência médica, independentemente de sua situação econômica, sob pena de não ter muito valor sua consignação em normas constitucionais?.

Também acerca do conceito de direito à saúde, afirma J. J. Gomes Canotilho:

[...] a natureza negativa, consiste no direito a exigir do Estado (ou de terceiros) que se abstenha de qualquer acto que prejudique a saúde; a natureza positiva, que significa o direito às medidas e prestações estaduais visando a prevenção das doenças e o tratamento delas ${ }^{10}$.

Gilmar Mendes Ferreira e Paulo Gustavo Gonet Branco ${ }^{11}$ ressaltam que o direito à saúde é um direito de todos, representando um direito individual, no sentido de um direito público subjetivo a políticas públicas que promovam, protejam e recuperem a saúde. E ainda um direito coletivo, no sentido de direito de proteção à saúde.

O direito à saúde é um dever do Estado, um direito fundamental de prestação de saúde que deve ser garantido mediante a execução de políticas públicas sociais e econômicas. Estas devem ser realizadas mediante políticas públicas de saúde, para as quais o Estado tem o dever de alocar recursos financeiros em prol de um acesso universal e igualitário aos serviços públicos de saúde.

Esses entendimentos estão determinados na Lei n. 8.080/1990 que estabelece o Sistema Único de Saúde (SUS) e que, em seu artigo 2º prescreve: "A saúde é um direito fundamental do ser humano, devendo o Estado prover as condições indispensáveis ao seu pleno exercício"12.

${ }^{8}$ SILVA, José Afonso da. op. cit., p. 187.

${ }^{9}$ ld., loc. cit.

${ }^{10}$ CANOTILHO, J.J. Gomes. Constituição da República portuguesa anotada. 3. ed. Coimbra: Coimbra Ed., 1984. p. 342.

${ }^{11}$ MENDES, Gilmar Ferreira; BRANCO, Paulo Gustavo Gonet. Curso de direito constitucional. 7. ed. São Paulo: Saraiva, 2012. p. 696.

${ }^{12}$ BRASIL. Lei n. 8.080, de 19 de setembro de 1990. Dispõe sobre as condições para a promoção, proteção e recuperação da saúde, a organização e o funcionamento dos serviços correspondentes e dá outras providências. Disponível em: http://www.planalto.gov.br/ccivil_03/leis//8080.htm. Acesso em: 22 ago. 2017. 
A CF/88, em seu artigo 196, preceitua a saúde como direito de todos e dever do Estado, concretizada mediante políticas econômicas e sociais aptas a possibilitar um acesso universal e igualitário às ações e serviços de saúde. Na mesma esteira, seu artigo 194, que trata da seguridade social, estabelece em seu parágrafo único, inciso I, que um dos objetivos da seguridade social (que inclui saúde, previdência social e assistência social) é a universalidade da cobertura e do atendimento.

Mas, afinal, qual é o âmbito de proteção dessa citada integralidade?

A universalidade da cobertura, também conhecida como universalidade objetiva, é aquela que visa a uma total cobertura das ações e dos serviços de saúde. Ela é relacionada, desta forma, com a proteção de todos os riscos sociais relativos à saúde da população.

Por sua vez, a universalidade do atendimento, ou universalidade subjetiva, tem relação direta com os destinatários do direito à saúde, ou seja, quais pessoas serão atendidas quando tiverem qualquer contingência sanitária. A universalidade do atendimento visa a estabelecer um sistema de saúde igualitário, sem qualquer discriminação quanto aos sujeitos detentores do direito à saúde. Aliás, como a própria Constituição consigna, o direito à saúde é um direito de todos e um dever do Estado, sendo possível perceber a amplitude do mandamento constitucional.

Vale ressaltar que, em sede de direitos legalmente assegurados, é de suma importância essa mudança no enquadramento constitucional da integralidade do direito à saúde. Essa positivação levou os autores de artigo específico sobre a integralidade da saúde a afirmarem que a saúde deve:

[...] ser garantida mediante políticas econômicas e sociais que visem à redução dos riscos de agravos e doenças e ao acesso universal e igualitário às ações e serviços públicos de saúde. Reconhecida como um direito, a saúde passou a ser objeto de atenção especial da sociedade e do Estado, o que gerou ampla inovação legislativa, significativa reorganização da administração pública e proliferação de garantias jurídicas constitucionais para a sua proteção. A saúde passa a ser um bem jurídico tutelado pelo Estado e pela sociedade, merecedora de garantias jurídicas eficazes para sua fruição ${ }^{13}$.

Isso porque, como afirmou Silvia Badim Marques, até a CF/88, a saúde não era tida como um direito de todos os cidadãos:

\footnotetext{
${ }^{13}$ AITH, Fernando; BUJDOSO, Yasmim; NASCIMENTO, Paulo Roberto; DALLARI, Sueli Gandolfi. Os princípios da universalidade e integralidade do sus sob a perspectiva da política de doenças raras e da incorporação tecnológica. Revista de Direito Sanitário, Brasil, v. 15, n. 1, p. 10-39, mar./jun. 2014. https://doi.org/10.11606/ issn.2316-9044.v15i1p10-39. Disponível em: www.revistas.usp.br/rdisan/article/viewFile/82804/85759. Acesso em: 26 nov. 2018.
} 
As Constituições anteriores à de 1988 não tratavam a saúde como um direito. Uma breve abordagem das Constituições republicanas nos permite constatar que a incorporação e construção dos direitos sociais, em especial do direito à saúde, se deram de forma vagarosa no Brasil. O sistema público de saúde brasileiro, até a promulgação da Constituição Federal de 1988, não merecia um tratamento constitucional específico e atendia somente aos indivíduos que contribuíssem à Previdência Social, ou seja, aqueles indivíduos que possuíssem carteira de trabalho assinada ${ }^{14}$.

A integralidade do direito à saúde é razão de ser do SUS, e a Lei n. 8.080/1990, que o regulamentou, também disciplinou o atendimento com base nas duas vertentes da universalidade, estabelecendo, como princípios das ações e serviços de saúde, tanto a universalidade subjetiva, em seu artigo $7^{\circ}$, inciso I, quanto a universalidade objetiva, denominada integralidade de assistência no artigo $7^{\circ}$, inciso II.

Nesse sentido, Fernando Aith et al. afirmam que:

Denominado Sistema Único de Saúde (SUS), o sistema público de saúde brasileiro foi modelado para o atendimento de todo ser humano em território nacional, de forma não discriminatória e equitativa. Criado pela Constituição Federal de 1988, na forma de uma rede regionalizada e hierarquizada de ações e serviços públicos de saúde, o SUS é constituído por serviços da União, dos estados, do Distrito Federal e dos municípios ${ }^{15}$.

Mas será possível, ao menos em um primeiro momento, alcançar essa direção constitucional?

O próprio texto constitucional esclarece que não. No mesmo artigo em que a Constituição preceitua como objetivo da seguridade social a universalidade da cobertura e do atendimento, ela restringe, momentaneamente, essa ampla proteção a partir de outros dois objetivos, estes estabelecidos em seu parágrafo único, inciso III: a seletividade e a distributividade.

A seletividade nada mais é do que uma restrição à universalidade objetiva. Assim, enquanto não for possível a cobertura de todas as contingências relacionadas ao direito à saúde, deverão ser selecionados alguns riscos específicos por parte do gestor público. Por outro lado, a distributividade é a limitação à universalidade subjetiva (ou de acesso): neste primeiro momento, em que não é possível a total concretização do direito à saúde, a distributividade permite ao gestor público

\footnotetext{
${ }^{14}$ MARQUES, Silvia Badim. O princípio constitucional da integralidade de assistência à saúde e o projeto de lei n. 219/2007: interpretação e aplicabilidade pelo poder judiciário. Revista de Direito Sanitário, Brasil, v. 10, n. 2, p. 64-86, jul./out. 2009. https://doi.org/10.11606/issn.2316-9044.v10i2p64-86. Disponível em: http://www.revistas.usp.br/rdisan/article/view/13163. Acesso em: 26 nov. 2018.

${ }^{15}$ AITH, Fernando; BUJDOSO, Yasmim; NASCIMENTO, Paulo Roberto; DALLARI, Sueli Gandolfi. op. cit., p. 12.
} 
restringir determinadas prestações de saúde a apenas uma parcela da população, a qual julgue mais necessitada.

Quanto à restrição da universalidade da cobertura e do atendimento em direito à saúde, o Relatório Mundial da Saúde de 2010, da Organização Mundial da Saúde ${ }^{16}$ (OMS), salienta que "os fundos comuns nunca serão capazes de cobrir $100 \%$ da população para 100\% dos custos e 100\% dos serviços necessários. Os países ainda terão que fazer escolhas difíceis quanto à melhor utilização desses fundos.”

Ainda que o Brasil tenha um amplo financiamento em direito à saúde, é impossível, ao menos em um primeiro momento, garantir a universalidade da cobertura e do atendimento, ou, como preferem alguns, a "assistência integral em saúde".

Octavio Luiz Motta Ferraz e Fabíola Sulpino Vieira ${ }^{17}$, analisando a problemática da judicialização de medicamentos, afirmam que, caso o Estado fornecesse a todos os que sofrem de hepatite viral crônica $\mathrm{C}$ e artrite reumatoide o remédio mais avançado e concedido pelo Poder Judiciário em ações individuais, o custo seria de aproximadamente $\mathrm{R} \$ 99,5$ bilhões, valor maior que o total previsto para o orçamento (que engloba todos os entes federativos) da saúde em 2007 (que foi de aproximadamente, ainda segundo os autores, R\$ 85,7 bilhões). Esse dado dos autores fica ainda mais elucidativo quanto constatamos que, atualmente, o SUS fornece esses medicamentos para artrite reumatoide e hepatite viral crônica $\mathrm{C}$ aos necessitados por meio dos chamados "protocolos clínicos", que nada mais são do que a manifestação da distributividade em direito à saúde.

Os protocolos clínicos têm, como um de seus fundamentos, a padronização do tratamento, inclusive farmacêutico, aos que sofrem de determinados males, de forma a racionalizar o tratamento e o eventual fornecimento de medicamentos necessários. A Lei n. 12.401/2011 ${ }^{18}$, que alterou a Lei n. 8.080/1990, previu, expressamente, os protocolos clínicos dentro do capítulo da assistência terapêutica e da incorporação de novas tecnologias ao SUS, sendo necessária observância, quando existente, para a dispensação de medicamentos, de acordo com o artigo 19-M.

Além disso, é possível perceber a ocorrência da restrição à universalidade subjetiva nas campanhas de vacinação governamentais, em que se selecionam grupos estabelecidos como de risco para a imunização contra certas doenças.

\footnotetext{
${ }^{16}$ ORGANIZAÇÃO MUNDIAL DA SAÚDE - OMS. 2010. Relatório Mundial da Saúde 2010: financiamento dos sistemas de saúde: o caminho para a cobertura universal. p. 2. Disponível em: https://www.who.int/ whr/2010/whr10_pt.pdf. Access in: 15 jun. 2017.

${ }^{17}$ FERRAZ, Octavio Luiz Motta; VIEIRA, Fabíola Sulpino. Direito à saúde, recursos escassos e equidade: os riscos da interpretação judicial dominante. Dados, Rio de Janeiro, v. 52, n. 1, p. 237, mar. 2009. http:// dx.doi.org/10.1590/S0011-52582009000100007. Disponível em: http://www.scielo.br/pdf/dados/ v52n1/v52n1a07.pdf. Acesso em: 06 set. 2017.

${ }^{18}$ BRASIL. Lei $n$. 12.401, de 28 de abril de 2011. Altera a Lei no 8.080, de 19 de setembro de 1990, para dispor sobre a assistência terapêutica e a incorporação de tecnologia em saúde no âmbito do Sistema Único de Saúde - SUS. Disponível em: http://www.planalto.gov.br/ccivil_03/_ato2011-2014/2011/lei/ I12401.htm. Acesso em: 22 ago. 2017.
} 
Por outro lado, a seletividade é claramente percebida dentro das ações de saúde nas edições da chamada Relação Nacional de Medicamentos Essenciais ${ }^{19}$ (Rename), que definem aqueles medicamentos fornecidos pelo poder público (federal, estadual e municipal) em razão de comprovada eficácia, custo-efetividade e imprescindibilidade, dentre o rol de possibilidades existentes no mercado farmacêutico.

As limitações constitucionais às duas faces da universalidade são fundamentais no caminhar em busca da total concretização do direito à saúde.

Os direitos sociais, segundo o Pacto Internacional sobre Direitos Econômicos, Sociais e Culturais ${ }^{20}$ e o Protocolo de San Salvador ${ }^{21}$, são direitos que têm como uma de suas características principais a progressividade, devendo, para sua concretização, ser aplicado o máximo de recursos disponíveis, ainda segundo os citados documentos internacionais.

Como compatibilizar a universalidade da cobertura e do atendimento em um direito para cuja concretização o regime jurídico estabelece a progressividade? $\mathrm{O}$ artigo 196 da CF/88 salienta que a implementação do direito à saúde se dá mediante política pública, que, segundo Maria Paula Dallari Bucci, “[...] incorpora elementos sobre a ação necessária e possível naquele momento determinado, naquele conjunto institucional, e projeta-os para o futuro mais próximo ${ }^{22}$ ".

Deve-se ter em mente que não há uma total discricionariedade administrativa ao gestor público, como pensam e criticam alguns. Nosso texto constitucional, dirigente como é, estabelece caminhos, diretrizes, direções ao gestor público na tomada de suas decisões, devendo ele, por exemplo, respeitar os objetivos traçados pela Constituição - tais como a obrigação da busca da redução das desigualdades sociais e regionais, prevista em seu artigo $3^{\circ}$, inciso III, e que em saúde é muito presente nas conhecidas endemias das regiões Norte e Nordeste, ou na prioridade da medicina preventiva dentro da política pública de saúde.

Nesse sentido, Luiza Cristina Fonseca Frischeisen ${ }^{23}$ afirma que há, na verdade, uma discricionariedade mínima do administrador em implementar as

${ }^{19}$ MINISTÉRIO DA SAÚDE. Secretaria de Ciência, Tecnologia e Insumos Estratégicos. Departamento de Assistência Farmacêutica e Insumos Estratégicos. Relação Nacional de Medicamentos Essenciais: RENAME 2017. Brasília: Ministério da Saúde, 2017. Disponível em: http://bvsms.saude.gov.br/bvs/ publicacoes/relacao_nacional_medicamentos_rename_2017.pdf/. Acesso em: 30 set. 2007.

${ }^{20}$ BRASIL. Decreto n. 591, de 06 de julho de 1992. Atos Internacionais. Pacto Internacional sobre Direitos Econômicos, Sociais e Culturais. Promulgação. Disponível em: http://www.planalto.gov.br/ccivil_03/ decreto/1990-1994/d0591.htm. Acesso em: 22 ago. 2017.

${ }^{21}$ BRASIL. Decreto n. 3321, de 30 de dezembro de 1999. Promulga o Protocolo Adicional à Convenção Americana sobre Direitos Humanos em Matéria de Direitos Econômicos, Sociais e Culturais "Protocolo de São Salvador", concluído em 17 de novembro de 1988, em São Salvador, El Salvador. Disponível em: http://www.planalto.gov.br/ccivil_03/decreto/d3321.htm. Acesso em: 22 ago. 2017.

${ }^{22}$ BUCCI, Maria Paula Dallari. 0 conceito de política pública em direito. In: BUCCI, Maria Paula Dallari (Org.). Políticas públicas: reflexões sobre o conceito jurídico. São Paulo: Saraiva, 2006. p. 19.

${ }^{23}$ FRISCHEISEN, Luiza Cristina Fonseca. Políticas públicas: a responsabilidade do administrador e do Ministério Público. São Paulo: Max Limonad, 2000. p. 96. 
políticas públicas constitucionais. Em sentido semelhante, afirma Zélia Luiza Pierdoná, ao analisar os princípios da seletividade e da distributividade, que

\begin{abstract}
a escolha não é totalmente discricionária, pois, além de a própria Constituição já ter apresentado os riscos a serem protegidos na previdência (doença, velhice, invalidez, morte etc.) e estabelecido a prevenção como prioridade na saúde, o segundo comando do princípio - distributividade - determina que a escolha dos riscos a serem cobertos recaia sobre prestações eu concretizem os objetivos da Ordem Social (bem-estar e justiça social) ${ }^{24}$.
\end{abstract}

Ora, se há uma prioridade, por exemplo, quanto à medicina preventiva, então o próprio texto constitucional estabelece como impossível a concretização imediata da universalidade da cobertura e do atendimento. Só há prioridade quando há escolha a ser tomada.

A legislação infraconstitucional ainda traz outras prioridades na formulação da política de saúde, dessa vez direcionadas a determinados grupos sociais, como a criança e o adolescente (art. $4^{\circ}$, parágrafo único, "c", da Lei n. 8.069/199025) e o idoso (art. $3^{\circ}$, parágrafo único, II, da Lei n. 10.741/200326).

Dessa forma, a universalidade, ou integralidade, do direito à saúde não pode ser concebida, ao menos inicialmente, como o fornecimento geral e irrestrito de prestações sanitárias a toda a população, sendo necessária, a partir do próprio texto constitucional, a criação de uma política pública racional e justificada que selecione o já citado "possível e necessário".

Essa visão em nada retira do Poder Judiciário a possibilidade de examinar demandas individuais e coletivas que tratem do descumprimento das promessas constitucionais ou da política pública instituída, desde que presentes parâmetros objetivos que partam, precipuamente, do conteúdo da integralidade do direito à saúde. Mas como é que o Supremo Tribunal Federal interpreta a citada universalidade?

\title{
II. A visão do STF
}

Acerca da atuação do Judiciário e a integralidade da saúde, Marco Antonio da Costa Sabino ${ }^{27}$ afirma que a atuação do Poder Judiciário deve ser pautada na elimi-

\footnotetext{
${ }^{24}$ PIERDONÁ, Zélia Luiza. Os princípios constitucionais de seguridade social como limitadores do ativismo judicial na proteção social. In: FRANCISCO, José Carlos (Coord.). Neoconstitucionalismo e atividade jurisdicional: do passivismo ao ativismo judicial. Belo Horizonte: Del Rey, 2012. p. 332.

${ }^{25}$ BRASIL. Lei n. 8.069, de 13 de julho de 1990. Dispõe sobre o Estatuto da Criança e do Adolescente e dá outras providências. Disponível em: http://www.planalto.gov.br/ccivil_03/leis/18069.htm. Acesso em: 22 ago. 2017.

${ }^{26}$ BRASIL. Lei n. 10.741, de 01 de outubro de 2003. Dispõe sobre o Estatuto do Idoso e dá outras providências. Disponível em: http://www.planalto.gov.br/ccivil_03/leis/2003/I10.741.htm. Acesso em: 22 ago. 2017.

${ }^{27}$ SABINO, Marco Antonio da Costa. Quando o judiciário ultrapassa seus limites constitucionais e institucionais: o caso da saúde. In: GRINOVER, Ada Pellegrini; WATANABE, Kazuo (Orgs.). O controle judicial de políticas públicas. Rio de Janeiro: Forense, 2011. p. 364.
} 
nação de lesões ou ameaças a direitos e em quando ocorrer a omissão do Estado por seus poderes Executivo e Legislativo, tendo em vista limitação do mínimo existencial e da reserva do possível, conforme determinações expressas no julgamento da ADPF $45^{28}$. Assim, o Poder Judiciário deve atuar com base no princípio da razoabilidade.

Luís Roberto Barroso ${ }^{29}$ afirma que as ações individuais deveriam requerer apenas medicamentos constantes das listas, que configuram o dever inequívoco do Estado no que toca ao direito à saúde. Assim, apenas ações coletivas seriam viáveis para a solicitação de alterações nas listas oficiais, pois tais ações teriam o condão de garantir a todos os interessados desfrutar igualmente do direito. Ficariam excluídos os medicamentos experimentais e haveria preferência por droga disponível no Brasil e medicamento genérico. Ainda clama pela fixação de entendimento de que a legitimidade passiva seja do ente responsável pela lista na qual consta medicamento negado.

Inúmeros são os julgados que versam sobre a temática de mínimo existencial, reserva do possível e direito à saúde. Uma pesquisa bastante simples - usando como critério os termos e "mínimo existencial" e "reserva do possível" - no site do STF dá a dimensão desse universo: são mais de 1.730 documentos localizados. Mas alguns julgados são paradigmáticos na análise de políticas públicas, principalmente no que toca à conclusão pretendida neste artigo, seja pelo caso enfrentado, seja pelo modo como o caso foi decidido.

Os julgamentos aqui apontados como paradigmáticos são reconhecidos como tal pelo próprio STF e lhe servem de base, sem, contudo, assumirem a condição técnica processual de precedente, que vincularia decisões futuras. Mas, na prática, esses julgados paradigmáticos acabam por assumir tal condição na medida em que são sempre referidos como fundamentação das decisões que se seguem a eles.

Com relação ao direito à saúde, a jurisprudência do STF foi construída, no final da década de 1990, baseada em uma ideia ampliativa de integralidade do direito à saúde, influenciando os demais tribunais do país quando da judicialização do direito à saúde.

Ocorre que, a partir de uma série de decisões da ministra Ellen Gracie, principalmente a Suspensão de Tutela Antecipada (STA) 91/AL ${ }^{30}$, houve uma

\footnotetext{
${ }^{28}$ SUPREMO TRIBUNAL FEDERAL - STF. Decisão monocrática em Medida Cautelar em Arguição de descumprimento de Preceito Fundamental n. 45/DF. Relator: Ministro Celso de Mello. 29 abr. 2004. Disponível em: http://stf.jus.br/portal/jurisprudencia/listarJurisprudencia.asp?s1=\%28ADPF\%24\%2ESCL $\mathrm{A} \% 2 \mathrm{E}+\mathrm{E}+45 \% 2 \mathrm{ENUME} \% 2 \mathrm{E} \% 29+\mathrm{NAO}+\mathrm{S} \% 2 \mathrm{EPRES} \% 2 \mathrm{E} \&$ base=baseMonocraticas\&url=http://tinyurl.com/ bu3e9ae. Acesso em: 22 ago. 2017.

${ }^{29}$ BARROSO, Luís Roberto. Da falta de efetividade à judicialização efetiva: direito à saúde, fornecimento gratuito de medicamentos e parâmetros para a atuação judicial. Revista da Procuradoria-Geral do Estado do Rio Grande do Sul, Porto Alegre, v. 31, n. 66, p. 99, jul./dez. 2007. Disponível em: https://www.pge. rs.gov.br/upload/arquivos/201703/22171856-rpge66livro.pdf. Acesso em: 09 jun. 2017.

${ }^{30}$ SUPREMO TRIBUNAL FEDERAL - STF. Suspensão de Tutela Antecipada n. 91/AL. Relatora: Ministra Ellen Gracie. 26 fev. 2007. Disponível em: http://stf.jus.br/portal/jurisprudencia/listarJurisprudenciaDetalhe.as p?s1=000138000\&base=basePresidencia. Acesso em: 25 set. 2019.
} 
mudança (ou ao menos tentativa de mudança) na interpretação do conteúdo da integralidade do direito à saúde, criando um conflito argumentativo dentro do próprio STF que só foi resolvido com o julgamento da STA $175 / \mathrm{CE}^{31}$, de relatoria do ministro Gilmar Mendes.

A partir desses julgados paradigmáticos, assim reconhecidos pelo STF, a STA 91/AL é a base de 23 acórdãos proferidos pelo STF e a STA 175/CE, de mais de 30 julgamentos posteriores proferidos pelo mesmo STF, e são, portanto, aptos a demonstrarem a visão do STF acerca da controvérsia em análise. Assim, é possível estabelecer qual é a visão do STF acerca do direito à saúde e, em especial, acerca da integralidade do referido direito.

Na STA 91/AL com julgamento da ministra Ellen Gracie, enquanto presidente do STF, o Estado de Alagoas, com fundamento no artigo $4^{\circ}$ da Lei $n$. $8.437 / 1992^{32}$ e no artigo $1^{\circ}$ da Lei n. $9.494 / 1997^{33}$, requereu a suspensão da execução da tutela antecipada concedida na Ação Civil Pública n. 001.06.014309-7, que determinou àquele ente federado o fornecimento de medicamentos necessários para o tratamento de pacientes renais crônicos em hemodiálise e pacientes transplantados.

O ente federado alegou, como fundamento, a ocorrência de grave lesão à economia pública, porquanto a liminar impugnada foi genérica ao determinar que o Estado fornecesse todo e qualquer medicamento necessário ao tratamento dos transplantados renais e pacientes renais crônicos, impondo-lhe a entrega de medicamentos de competência de outros entes federativos. Ressaltou ainda que ao Estado de Alagoas compete o fornecimento de medicamentos relacionados no Programa de Medicamentos Excepcionais e de alto custo, em conformidade com a Lei n. 8.080/1990.

Em sua manifestação, a ministra asseverou que ficou devidamente configurada a lesão à ordem pública, na medida em que a execução de decisões desta natureza afeta o já abalado sistema público de saúde. Seu entendimento parte do fato de que a gestão da política nacional de saúde é feita de forma regionalizada, buscando uma maior racionalização entre o custo e o benefício dos tratamentos que devem ser fornecidos gratuitamente, a fim de atingir o maior número possível de beneficiários. Especialmente acerca da integralidade do direito à saúde, a ministra afirmou que a norma do artigo $196 \mathrm{da} \mathrm{CF} / 88$, que assegura o direito à saúde, refere-se, em

\footnotetext{
${ }^{31}$ SUPREMO TRIBUNAL FEDERAL - STF. Agravo Regimental na Suspensão de Tutela Antecipada n. 175/ CE. Relator: Ministro Gilmar Mendes. 17 mar. 2010. Disponivel em: http://redir.stf.jus.br/paginadorpub/ paginador.jsp?docTP=AC\&docID=610255. Acesso em: 25 set. 2019.

${ }^{32}$ BRASIL. Lei $n$. 8.437, de 30 de junho de 1992. Dispõe sobre a concessão de medidas cautelares contra atos do Poder Público e dá outras providências. Disponível em: http://www.planalto.gov.br/ccivil_03/leis/ 18437.htm. Acesso em: 22 ago. 2017.

${ }^{33}$ BRASIL. Lei n. 9.494, de 10 de setembro de 1997. Disciplina a aplicação da tutela antecipada contra a Fazenda Pública, altera a Lei $n^{\circ} 7.347$, de 24 de julho de 1985, e dá outras providências. Disponível em: http://www.planalto.gov.br/ccivil_03/leis/19494.htm. Acesso em: 22 ago. 2017.
} 
princípio, à efetivação de políticas públicas que alcancem a população como um todo, assegurando-lhe acesso universal e igualitário, e não a situações individualizadas, não podendo uma pretensão individual inviabilizar todo o sistema público de saúde.

Assim, o pedido de suspensão de tutela antecipada foi parcialmente deferido, tão somente para limitar a responsabilidade da Secretaria Executiva de Saúde do Estado de Alagoas ao fornecimento dos medicamentos contemplados na Portaria n. 1.318/2013 do Ministério da Saúde ${ }^{34}$.

Desse julgado, depreende-se a restrição da integralidade do direito à saúde ao que estabelece a lei. Nessa medida, o direito individual não é absoluto, ressaltando-se a validade da política pública estabelecida pela legislação, na medida em que o dever do ente público não está em atender a necessidade individual, mas em cumprir o legislado.

O segundo julgamento paradigmático foi a Arguição de Descumprimento de Preceito Fundamental (ADPF) 45, referida em mais de 65 julgamentos pelo STF, que tratou do veto emanado pelo presidente da República e que incidiu sobre o parágrafo $2^{\circ}$ do artigo 55 (posteriormente renumerado para art. 59), de proposição legislativa que se converteu na Lei n. 10.707/2003 ${ }^{35}$ (Lei de Diretrizes Orçamentárias - LDO), destinada a fixar as diretrizes pertinentes à elaboração da lei orçamentária anual de 2004.

A alegação de base da ação é que o veto presidencial importou em desrespeito a preceito fundamental decorrente da Emenda Constitucional n. 29/2000 ${ }^{36}$, promulgada justamente para garantir recursos financeiros mínimos a serem aplicados nas ações e serviços públicos de saúde. No entanto, o presidente da República, logo após o veto parcial questionado, remeteu ao Congresso Nacional novo projeto de lei. Transformado na Lei n. 10.777/2003, o projeto restaurou a integralidade do texto vetado, ainda a tempo de ser aplicado na criação da Lei Orçamentária Anual (LOA) de 2004. Assim, suprimiu-se o motivo do ajuizamento da ação constitucional.

Não obstante, o ministro Celso de Mello refletiu sobre pontos importantes, em especial, acerca da implementação de políticas públicas, da cláusula da "reserva do possível" e do "mínimo existencial" em matéria do direito à saúde. Em

\footnotetext{
${ }^{34}$ MINISTÉRIO DA SAÚDE. Portaria n. 1.318, de 25 de novembro de 2013. Aprova o Protocolo Clínico e Diretrizes Terapêuticas da Doença de Wilson. Disponível em: http://bvsms.saude.gov.br/bvs/saudelegis/ sas/2013/prt1318_25_11_2013.html. Acesso em: 22 ago. 2017.

${ }^{35}$ BRASIL. Lei $n$. 10.707, de 30 de julho de 2003. Dispõe sobre as diretrizes para a elaboração da lei orçamentária de 2004 e dá outras providências. Disponível em: http://www.planalto.gov.br/ccivil_03/ leis/2003/I10.707.htm. Acesso em: 22 ago. 2017.

${ }^{36}$ BRASIL. Emenda Constitucional n. 29, de 13 de setembro de 2000. Altera os arts. 34, 35, 156, $160,167 \mathrm{e}$ 198 da Constituição Federal e acrescenta artigo ao Ato das Disposições Constitucionais Transitórias, para assegurar os recursos mínimos para o financiamento das ações e serviços públicos de saúde. Disponível em: http://www.planalto.gov.br/ccivil_03/constituicao/emendas/emc/emc29.htm. Acesso em: 22 ago. 2017.
} 
relação ao papel do Poder Judiciário em matéria de políticas públicas, o ministro salientou que não é competência ordinária, no âmbito das funções institucionais do Poder Judiciário - e da Suprema Corte, em especial -, a atribuição de formular e de implementar políticas públicas. Este encargo é, primariamente, dos poderes Legislativo e Executivo. No entanto, tal incumbência, embora em bases excepcionais, poderá atribuir-se ao Poder Judiciário, se e quando os órgãos estatais competentes, por descumprirem os encargos político-jurídicos que sobre eles incidem, vierem a comprometer, com tal comportamento, a eficácia e a integridade de direitos individuais e/ou coletivos impregnados de estatura constitucional, ainda que derivados de cláusulas revestidas de conteúdo programático.

Em relação à reserva do possível, afirmou o ministro que a realização dos direitos de segunda geração, econômicos, sociais e culturais, é caracterizada pela gradualidade de seu processo de concretização - dado o inescapável vínculo financeiro subordinado às possibilidades orçamentárias do Estado. Assim, comprovada objetivamente a incapacidade econômico-financeira da pessoa estatal, desta não se poderá razoavelmente exigir, considerada a limitação material referida, a imediata efetivação do comando fundado no texto da Carta Política. Não obstante, não é lícito ao Poder Público, em tal hipótese - mediante indevida manipulação de sua atividade financeira e/ou político-administrativa - criar obstáculo artificial que revele o ilegítimo, arbitrário e censurável propósito de fraudar, frustrar e inviabilizar o estabelecimento e a preservação, em favor da pessoa e dos cidadãos, de condições materiais mínimas de existência.

Concluiu o ministro que a cláusula da reserva do possível - ressalvada a ocorrência de justo motivo objetivamente aferível - não pode ser invocada pelo Estado com a finalidade de se exonerar do cumprimento de suas obrigações constitucionais, notadamente quando, dessa conduta governamental negativa, puder resultar nulificação ou até mesmo aniquilação de direitos constitucionais impregnados de um sentido de essencial fundamentalidade, estando a reserva do possível lastreada em dois pontos: (1) a razoabilidade da pretensão individual/social deduzida em face do Poder Público e, de outro, (2) a existência de disponibilidade financeira do Estado para tornar efetivas as prestações positivas dele reclamadas.

Assim, nessa decisão, percebe-se uma preocupação em aclarar os contornos da efetivação de direitos sociais, o que implica na integralidade da saúde, ao se fixarem pontos para a reflexão da reserva do possível, reconhecendo a problemática financeira sem, contudo, eximir o Estado de suas responsabilidades constitucionais.

A questão ganha critérios objetivos com a STA 175/CE. Esse caso paradigmático trata de uma adolescente com doença neurodegenerativa rara, para cujo desenvolvimento ser detido requer medicamento reconhecido, e que é oriunda de uma família sem recursos para tratamento (estimado em $\mathrm{R} \$ 52$ mil mensais em 2006). O medicamento só foi registrado na Agência Nacional de Vigilância Sanitária (Anvisa) 
no curso da ação e, portanto, à época da distribuição da ação, o medicamento de alto custo não era contemplado pela lista do SUS (Rename) nem pelo programa de medicamentos de dispensação em caráter excepcional.

O julgado afirma que o alto custo do medicamento não é, por si só, motivo para seu não fornecimento, dado que tal fato não permite a verificação de grave lesão à ordem, à economia e à saúde públicas. A intervenção do Poder Judiciário, segundo texto do julgado, não afronta o princípio da separação dos poderes, dado que há a possibilidade de o Judiciário intervir na política pública.

Nesse julgamento, foram realizadas audiências públicas de 27 de abril a 7 de maio de 2009 para a contemplação das manifestações que pudessem elucidar o julgamento. Foram fiados critérios objetivos e claros acerca da integralidade da saúde a partir do julgamento da concessão de medicamentos. Quais sejam:

\section{Verificação de existência de política pública}

Não cabe ao Judiciário formular a política pública de saúde, mas é sua obrigação verificar se as políticas existentes atendem aos ditames constitucionais de acesso universal e igualitário.

1.1 Se já existe política pública, o Judiciário determina cumprimento, não a criação da política pública.

1.2 Se não existe política pública, deve ser analisado se há omissão legislativa ou administrativa, motivação da decisão administrativa de não fornecer medicamento e vedação legal expressa à dispensação do medicamento em questão.

2. Concessão apenas de medicamentos registrados na Anvisa

A Lei n. 6.360/1976, em seu art. 12, determina que todo medicamento deve ser registrado na Anvisa. Apenas em caráter excepcional poderão ser concedidos medicamentos de programas com organismos internacionais de saúde.

\section{Negativa de concessão do medicamento pelo SUS}

Deve-se adotar e cumprir o princípio da "medicina com base em evidências": apenas medicamentos com protocolos estabelecidos podem ser concedidos.

Deve-se analisar a diferença entre tratamentos EXPERIMENTAIS e tratamentos novos, evitando tratamentos experimentais e assegurando tratamentos novos se verificados cientificamente pela comunidade médica. 


\section{Adequada instrução processual}

A instrução processual é fundamental para que a decisão judicial mantenha sua qualidade. Assim, sempre deve ser exigida prova da situação/necessidade do pleiteante. Também o ente público demandado deve observar a correta instrução processual no sentido de apurar e informar todas as circunstâncias do caso.

Essa decisão de Gilmar Mendes buscou estabelecer balizas para toda a judicialização do direito à saúde, adotando o STF um critério intermediário quanto à abrangência do conteúdo de integralidade do direito à saúde. Apesar disso, é possível perceber que o ministro Gilmar Mendes, em seu voto, relativiza as situações mais controvertidas na doutrina e na jurisprudência para possibilitar ao juiz, no caso concreto, fornecer ou não determinado medicamento pleiteado em juízo. O ministro, por exemplo, abre exceção para o fornecimento de medicamentos experimentais e não registrados na Anvisa, desde que esses medicamentos estejam previstos em programas de organismos internacionais. Da mesma forma, suaviza a exigência da concessão de medicamentos previstos em protocolos, alargando a noção de "medicina baseada em evidências" para além do âmbito Conitec e do Ministério da Saúde, atingindo toda a comunidade médica.

\section{Considerações finais}

Assim como nos Estados Unidos, o acesso às ações e aos serviços de saúde, por sua vertente tanto objetiva quanto subjetiva, e o custo para a total concretização do direito à saúde são desafios que obrigam o gestor público a selecionar o melhor e mais completo modo de atuação em busca da garantia do direito à saúde.

O direito à saúde é, sim, dentro do sistema constitucional e infraconstitucional brasileiro, um direito universal. Só que é necessário que os intérpretes compreendam que essa universalidade, na verdade, constitui um caminhar, uma busca pela completa proteção de todas as contingências sanitárias de todos os indivíduos.

A Audiência Pública n. 4 e a decisão do ministro Gilmar Mendes na STA 175/CE foram fundamentais não só por estabelecer parâmetros claros e objetivos (ainda que não tão claros e objetivos) para a integralidade no direito à saúde e para a forma de atuação do Judiciário, mas principalmente para iniciar o debate sobre a forma de atuação de todos os poderes na concretização dos direitos sociais, principalmente do direito à saúde.

Os atores jurídicos são fundamentais na concretização dos direitos sociais, sendo necessária, entretanto, uma compreensão correta do conteúdo do direito à saúde e de sua forma de implementação para o exercício dessa relevante função constitucional. $\mathrm{O}$ debate, mesmo com o término da Audiência Pública n. 4 e do estabelecimento dos parâmetros pelo ministro Gilmar Mendes, ainda está ocorrendo, faltando agora uma conclusão clara dos atores jurídicos quanto a seu papel. 


\section{Referências}

AITH, Fernando; BUJDOSO, Yasmim; NASCIMENTO, Paulo Roberto; DALLARI, Sueli Gandolfi. Os princípios da universalidade e integralidade do sus sob a perspectiva da política de doenças raras e da incorporação tecnológica. Revista de Direito Sanitário, Brasil, v. 15, n. 1, p. 10-39, mar./jun. 2014. https://doi.org/10.11606/issn.2316-9044.v15i1p10-39. Disponível em: www.revistas.usp.br/rdisan/article/viewFile/82804/85759. Acesso em: 26 nov. 2018.

BARROSO, Luís Roberto. Da falta de efetividade à judicialização efetiva: direito à saúde, fornecimento gratuito de medicamentos e parâmetros para a atuação judicial. Revista da Procuradoria-Geral do Estado do Rio Grande do Sul, Porto Alegre, v. 31, n. 66, p. 89-114, jul./ dez. 2007. Disponível em: https://www.pge.rs.gov.br/upload/arquivos/201703/22171856rpge66livro.pdf. Acesso em: 09 jun. 2017.

BONAVIDES, Paulo. Curso de direito constitucional. 24. ed. São Paulo: Malheiros, 2009.

BUCCI, Maria Paula Dallari. O conceito de política pública em direito. In: BUCCI, Maria Paula Dallari (Org.). Políticas públicas: reflexões sobre o conceito jurídico. São Paulo: Saraiva, 2006.

CANOTILHO, J.J. Gomes. Constituição da República portuguesa anotada. 3. ed. Coimbra: Coimbra Ed., 1984.

FERRAZ, Octavio Luiz Motta; VIEIRA, Fabíola Sulpino. Direito à saúde, recursos escassos e equidade: os riscos da interpretação judicial dominante. Dados, Rio de Janeiro, v. 52, n. 1, p. 223-251, mar. 2009. http://dx.doi.org/10.1590/S0011-52582009000100007. Disponível em: http://www.scielo.br/pdf/dados/v52n1/v52n1a07.pdf. Acesso em: 06 set. 2017.

FRISCHEISEN, Luiza Cristina Fonseca. Políticas públicas: a responsabilidade do administrador e do Ministério Público. São Paulo: Max Limonad, 2000.

FUCHS, Victor R. The future of health policy. 3. reprint. Harvard: Harvard University Press, 1997.

MARQUES, Silvia Badim. O princípio constitucional da integralidade de assistência à saúde e o projeto de lei n. 219/2007: interpretação e aplicabilidade pelo poder judiciário. Revista de Direito Sanitário, Brasil, v. 10, n. 2, p. 64-86, jul./out. 2009. https://doi.org/10.11606/issn.23169044.v10i2p64-86. Disponível em: http://www.revistas.usp.br/rdisan/article/view/13163. Acesso em: 26 nov. 2018.

MENDES, Gilmar Ferreira; BRANCO, Paulo Gustavo Gonet. Curso de direito constitucional. 7. ed. São Paulo: Saraiva, 2012.

MINISTÉRIODA SAÚDE. Secretaria de Ciência, Tecnologia e Insumos Estratégicos. Departamento de Assistência Farmacêutica e Insumos Estratégicos. Relação Nacional de Medicamentos Essenciais: RENAME 2017. Brasília: Ministério da Saúde, 2017. Disponível em: http://bvsms.saude.gov.br/ bvs/publicacoes/relacao_nacional_medicamentos_rename_2017.pdf/. Acesso em: 30 set. 2007.

ORGANIZAÇÃO MUNDIAL DA SAÚDE - OMS. Relatório Mundial da Saúde 2010: financiamento dos sistemas de saúde: o caminho para a cobertura universal. Disponível em: https://www.who.int/whr/2010/whr10_pt.pdf. Access in: 15 jun. 2017. 
ORGANIZATION FOR ECONOMIC COOPERATION AND DEVELOPMENT - OECD. Spending on health: latest trends. Available in: http://www.oecd.org/els/health-systems/healthdata.htm. Acesso em: Nov. 20, 2018.

PIERDONÁ, Zélia Luiza. Os princípios constitucionais de seguridade social como limitadores do ativismo judicial na proteção social. In: FRANCISCO, José Carlos (Coord.). Neoconstitucionalismo e atividade jurisdicional: do passivismo ao ativismo judicial. Belo Horizonte: Del Rey, 2012.

SABINO, Marco Antonio da Costa. Quando o judiciário ultrapassa seus limites constitucionais e institucionais: o caso da saúde. In: GRINOVER, Ada Pellegrini; WATANABE, Kazuo (Orgs.). O controle judicial de políticas públicas. Rio de Janeiro: Forense, 2011.

SILVA, José Afonso da. Curso de direito constitucional positivo. 32. ed. São Paulo: Malheiros, 2008.

Alexandre Luna da Cunha - Doutorado em Direito pela Universidade Presbiteriana Mackenzie. Professor da Universidade São Judas. São Paulo/SP, Brasil. E-mail: lunadacunha@yahoo.com.br. 